\title{
The Role of Trogocytosis in the Modulation of Immune Cell Functions
}

\author{
Kensuke Miyake *(D) and Hajime Karasuyama \\ Inflammation, Infection \& Immunity Laboratory, Advanced Research Institute, Tokyo Medical and Dental \\ University (TMDU), Tokyo 113-8510, Japan; karasuyama.mbch@tmd.ac.jp \\ * Correspondence: miyake.mbch@tmd.ac.jp; Tel.: +81-3-5803-4609
}

Citation: Miyake, K.; Karasuyama, $\mathrm{H}$. The Role of Trogocytosis in the Modulation of Immune Cell Functions. Cells 2021, 10, 1255. https://doi.org/10.3390/cells10051255

Academic Editors: Ryuta Koyama and Kumiko Nakada-Tsukui

Received: 30 April 2021

Accepted: 17 May 2021

Published: 19 May 2021

Publisher's Note: MDPI stays neutral with regard to jurisdictional claims in published maps and institutional affiliations.

Copyright: (C) 2021 by the authors. Licensee MDPI, Basel, Switzerland. This article is an open access article distributed under the terms and conditions of the Creative Commons Attribution (CC BY) license (https:/ / creativecommons.org/licenses/by/ $4.0 /)$.

\begin{abstract}
Trogocytosis is an active process, in which one cell extracts the cell fragment from another cell, leading to the transfer of cell surface molecules, together with membrane fragments. Recent reports have revealed that trogocytosis can modulate various biological responses, including adaptive and innate immune responses and homeostatic responses. Trogocytosis is evolutionally conserved from protozoan parasites to eukaryotic cells. In some cases, trogocytosis results in cell death, which is utilized as a mechanism for antibody-dependent cytotoxicity (ADCC). In other cases, trogocytosismediated intercellular protein transfer leads to both the acquisition of novel functions in recipient cells and the loss of cellular functions in donor cells. Trogocytosis in immune cells is typically mediated by receptor-ligand interactions, including TCR-MHC interactions and Fc $\gamma$ receptor-antibody-bound molecule interactions. Additionally, trogocytosis mediates the transfer of MHC molecules to various immune and non-immune cells, which confers antigen-presenting activity on non-professional antigen-presenting cells. In this review, we summarize the recent advances in our understanding of the role of trogocytosis in immune modulation.
\end{abstract}

Keywords: trogocytosis; antibody-dependent cellular cytotoxicity (ADCC); T cell receptor (TCR); major histocompatibility complex (MHC); Fc $\gamma$ receptor; NK receptor; cross-dressing; Th2 differentiation; intracellular bacteria

\section{Introduction}

In the past decade, trogocytosis (named from the ancient Greek trogo-, which means gnaw or nibble) has been attracting increasing attention in the vast fields of biology research, including immunology, microbiology, neurology, and developmental biology [1-7]. Trogocytosis is an active process, in which one cell rapidly acquires the fraction of another cell in a cell contact-dependent manner [8] (Figure 1). Trogocytosis is typically distinguished from phagocytosis, which indicates engulfment of the entire cell body (Figure 1).

Trogocytosis was first documented in the field of microbiology in 1979. Brown discovered that Naegleria fowleri, known as "brain-eating amoeba," nibbles mouse-embryo cells in a piecemeal fashion, a phenomenon termed trogocytosis [9]. In amoeba species, trogocytosis is a means of killing host cells to invade host tissues [10-12]. In the field of immunology, the transfer of major histocompatibility complex (MHC) proteins or immunoglobulins from B cells to T cells was reported in the 1970s [13,14]. In the early 1980s, host-derived MHC proteins were demonstrated to be acquired by donor-derived thymocytes in the system of bone marrow-chimeric mice [15,16]. In 2003, Joly and Hudrisier coined the term trogocytosis to explain the phenomenon of membrane protein transfer after immunological synapse formation in T cells, B cells, and natural killer (NK) cells [8]. To date, trogocytosis has been observed in various types of immune cells, including macrophages [17], dendritic cells (DCs) [18], neutrophils [19], basophils [20], and innate lymphoid cells (ILCs) [21] Trogocytosis has also been reported in non-immune cells, including lymph node stromal cells [22] and mesenchymal stromal cells [23]. Furthermore, trogocytosis by microglia contributes to brain homeostasis by pruning axons to remodel neurons [24-26]. 
(A) Phagocytosis

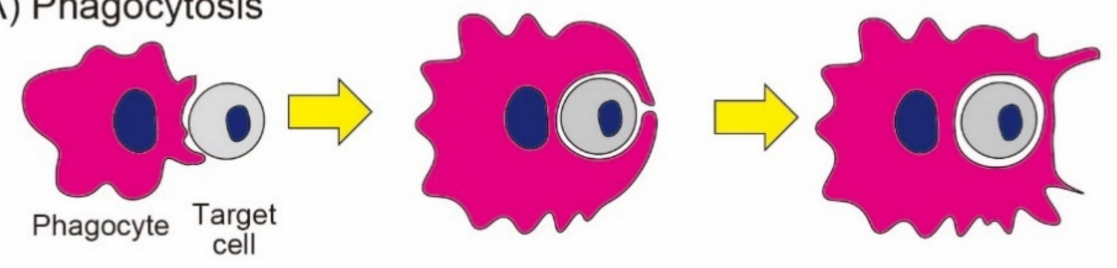

(B) Trogocytosis

1) Trogocytosis-mediated cell killing
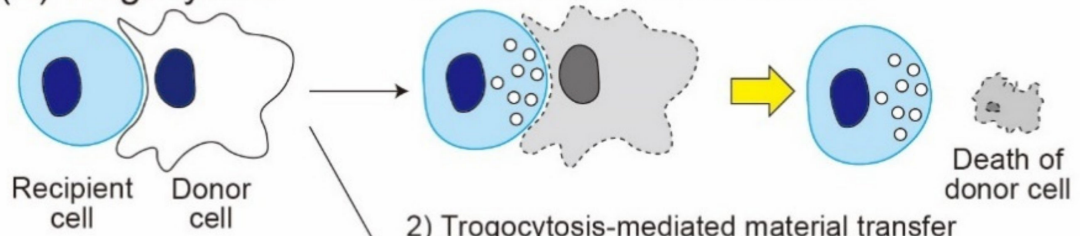

2) Trogocytosis-mediated material transfer

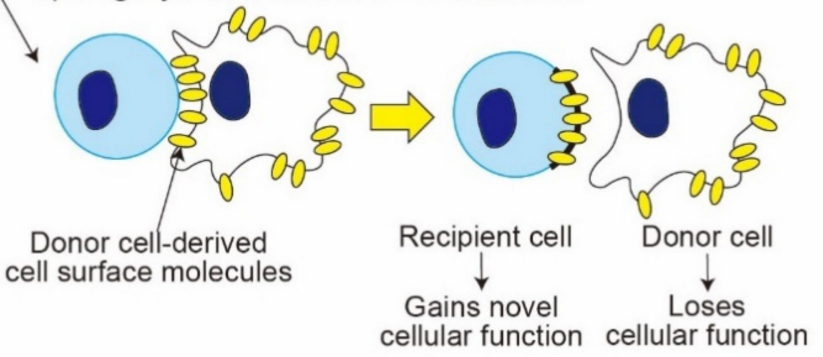

Figure 1. Characteristics of phagocytosis vs. trogocytosis. (A) In the process of phagocytosis, phagocytes swallow the whole cell body of target cells; (B) in the process of trogocytosis, recipient cells nibble the cell body of donor cells. Trogocytosis results in either (1) the death of target cells (trogocytosis-mediated cell death) or (2) the transfer of cell surface molecules, together with membrane patches, from donor cells to recipient cells (trogocytosis-mediated material transfer).

In the process of trogocytosis, recipient cells acquire membrane fractions, including cell surface molecules, from donor cells. Vanherbergen et al. reported that $\sim 3 \%$ of cell surface receptors on donor cells are rapidly transferred to recipient cells in trogocytosis by NK cells [27]. Therefore, recipient cells can gain novel functions by acquiring molecules from donor cells, while donor cells may reduce their cellular functions by the deprivation of their cell surface molecules. Moreover, in some cases, trogocytosis even results in the death of donor cells via a process called trogoptosis [28]. Thus, trogocytosis can modulate the function of both donor and recipient cells [1,2,8,29-32]. In this review, we summarize the immune-modulatory effects of trogocytosis. First, we provide an overview of trogocytosis-mediated cell death. Second, we focus on trogocytosis triggered by ligandreceptor interactions, including $\mathrm{T}$ cell receptor (TCR)/MHC and $\mathrm{F}_{\mathrm{c}} \gamma$ receptor/antibodybound cell surface molecule interactions. Finally, we discuss the trogocytosis observed in other immune cells, including basophils, DCs, and innate lymphoid cells.

\section{Trogocytosis-Mediated Cell Death}

As described above, trogocytosis by amoebae leads to the death of host cells [6]. Amoebic trogocytosis is mainly studied by using Entamoeba histolytica, a causative microbe of amoebiasis in humans. Ralston et al. reported that amoebae rapidly extract cell fragments from living Jurkat cells via trogocytosis, leading to the upregulation of the intracellular calcium concentration and the death of Jurkat cells [10] (Figure 2A). Importantly, amoebae perform trogocytosis-mediated cell killing only when target cells are alive, whereas amoebae perform phagocytosis of target cells when cells are dead [10,11]. Although similar processes are involved in both amoebic trogocytosis and phagocytosis, including Gal/GalNac lectin-mediated cell adhesion, requirement of actin, signaling through phsphoinositol-3 kinase (PI3K), and lysosomal acidification [10,12,33], several reports have implied that the molecular pathways in trogocytosis and phagocytosis are different $[6,11]$. A recent report demonstrated that AGC family kinase 1 (AGCK1), a molecule downstream 
of PI3K, is specifically involved in trogocytosis but not in phagocytosis [11], even though AGCK2 is involved in both. Furthermore, a cysteine protease inhibitor impairs amoebic trogocytosis but not phagocytosis, suggesting the possible involvement of a certain amoebic cysteine protease in trogocytosis [34]. Trogocytosis in amoebae would have been discussed in detail by other articles in this issue.

Mammalian immune cells can perform trogocytosis-mediated killing of pathogens. Mercer et al. reported that human neutrophils kill Trichomonas vaginalis parasites via trogocytosis [35]. When human neutrophils are co-cultured in vitro with T. vaginalis parasites, neutrophils rapidly nibble the cell body of $T$. vaginalis, leading to the death of parasites. As observed in trogocytosis by amoebae, human neutrophils trogocytose live parasites, but not heat-inactivated dead parasites.

Moreover, trogocytosis-mediated cell death is utilized in antibody-dependent cellular cytotoxicity (ADCC) against cancer cells by neutrophils and macrophages $[28,36,37]$ (Figure 2B). Matlung et al., identified that mouse and human neutrophils nibble antibodyopsonized cancer cells, leading to the necrotic cell death of cancer cells (a process designated as trogoptosis) [28]. Similar to amoebic trogocytosis, neutrophil trogocytosis and cytotoxicity against cancer cells are dependent on PI3K, a signaling molecule downstream of the Fcy receptor. Trogoptosis by neutrophils is dependent on CD11b/CD18 (Mac-1) integrin-mediated conjugation between neutrophils and cancer cells [28,37]. Interestingly, "don't eat-me signal" CD47 on cancer cells inhibits neutrophil trogoptosis via interaction with signal regulatory protein a (SIRPa), which provides mechanistic insight into the CD47SIRPa checkpoint blockade [28,37]. Velumurugan et al., reported a similar trogoptosis phenomenon, in which mouse and human macrophages kill antibody-opsonized cancer cells [36]. Moreover, a recent report revealed that mouse and human vaginal neutrophils can eliminate sperms via trogocytosis, to prevent excess inflammation triggered by exogeneous sperms [38]. Taken together, the mechanisms of trogocytosis-mediated cell death can be operative in both amoeba parasites and mammalian immune cells, suggesting the evolutional conservation of this phenomenon in eukaryotic cells.

\section{(A) Trogocytosis by amoebae}

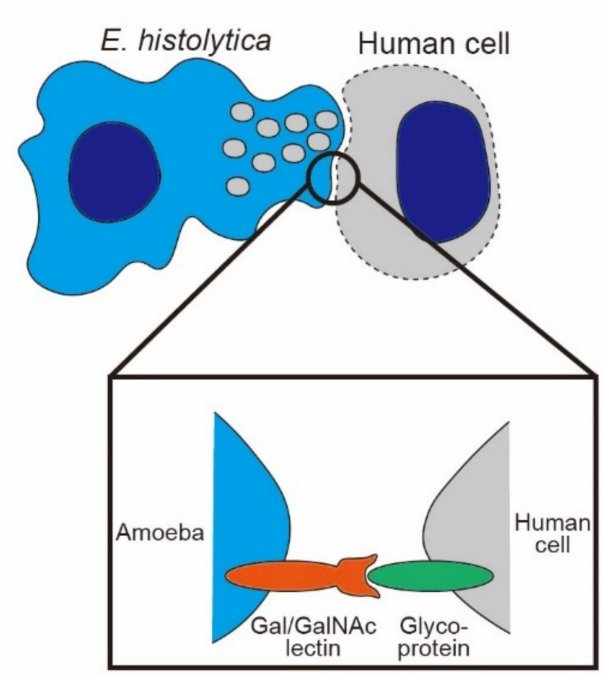

(B) Trogoptosis by neutrophils

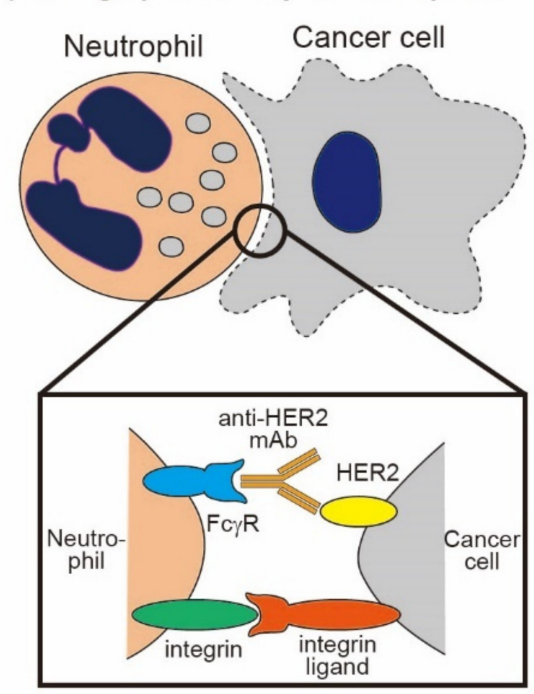

Figure 2. Trogocytosis-mediated cell death by amoebae and neutrophils. (A) Amoebae nibble human cells via trogocytosis, leading to the death of human cells. The interaction between amoebae and human cells is dependent on Gal/GalNAc lectin expressed on amoebae; (B) neutrophils nibble antibody-opsonized cancer cells via trogocytosis, resulting in cancer cell death (a process called trogoptosis). Trogoptosis by neutrophils is dependent on Fc $\gamma \mathrm{R}$ and Mac-1 integrin expressed on neutrophils. 


\section{Trogocytosis Triggered by LIGAND-Receptor Interaction-1: TCR-Mediated Trogocytosis}

\subsection{Overview of Trogocytosis Triggered by TCR-MHC Interaction}

In most cases, trogocytosis in immune cells requires ligand-receptor interactions [8]. TCR-MHC interaction is a well-characterized one that triggers trogocytosis. Upon stimulation of TCR on T cells by peptide-MHC complexes on antigen-presenting cells (APCs), an immunological synapse is formed between T cells and APCs. An immunological synapse consists of a central supramolecular activation cluster (cSMAC) enriched with TCR and intracellular signaling molecules, and a peripheral supramolecular activation cluster (pSMAC) enriched with integrins that surrounds cSMAC [39]. The formation of an immunological synapse results in the internalization of TCR and the transfer of peptideMHC (pMHC) complexes, together with membrane fragments of APCs, onto the surface of T cells [40-42]. As observed in trogocytosis by amoebae, TCR-mediated trogocytosis is dependent on both actin polymerization and the TCR signaling pathway, including Src kinase and PI3K [43,44]. Moreover, the formation of an immunological synapse is considered to play a key role in TCR-mediated trogocytosis. Indeed, trogocytosis is abrogated by the blockade of either co-stimulatory molecules (CD28-CD80/CD86 interactions) or integrins (interactions between lymphocyte function-associated antigen 1 (LFA-1) and intercellular adhesion molecule-1 (ICAM-1)) [45]. Interestingly, both co-stimulatory molecules (e.g., CD80, CD86, and OX-40 ligand) and integrin ligands (e.g., ICAM-1) are also transferred, together with pMHC complexes [45-47]. These results imply that a wide variety of molecules present in the immunological synapse are transferred upon TCR-mediated trogocytosis. However, it is worth noting that only limited sets of cell surface molecules are selectively transferred in trogocytosis $[48,49]$.

In general, $\mathrm{CD}^{+} \mathrm{T}$ cells capture peptide-MHC class II (pMHC-II) complexes from APCs, whereas $\mathrm{CD}^{+} \mathrm{T}$ cells acquire peptide-MHC class I (pMHC-I) complexes from APCs. Several reports indicate that $\mathrm{CD} 4^{+} \mathrm{T}$ cells can acquire both cognate pMHC-II and bystander PMHC-I complexes, possibly because of the localization of bystander PMHC-I in the proximity of cognate pMHC-II complexes [50-52]. Likewise, $\mathrm{CD} 8^{+} \mathrm{T}$ cells can acquire both cognate pMHC-I and bystander pMHC-II complexes [53].

Martínez-Martín et al. revealed that small GTPases, TC21 and RhoG, play central roles in TCR internalization and the trogocytosis of MHC-II upon immunological synapse formation between $\mathrm{CD}^{+} \mathrm{T}$ cells and APCs [44]. TC21 and RhoG also contribute to the trogocytosis of MHC-I in CD8 ${ }^{+} \mathrm{T}$ cells, indicating the essential roles of these small GTPases in TCR-mediated trogocytosis in both $\mathrm{CD}^{+}$and $\mathrm{CD} 8^{+} \mathrm{T}$ cells. Upon formation of an immunological synapse, TC21 and RhoG are internalized, together with TCR. Importantly, $\mathrm{CD}^{+} \mathrm{T}$ cells deficient of TC21 or RhoG fail to internalize TCR and capture MHC-II from APCs, demonstrating their role in TCR-mediated trogocytosis. An in vitro study using Jurkat cells further revealed that RhoG activation in T cells is dependent on TC21 and PI3K. Since TC21 is reported to activate the PI3K pathway [54], one may assume that the immunological synapse induces TC21 activation that, in turn, activates RhoG down-stream of PI3K, leading to the trogocytosis of pMHC complexes.

\subsection{The Impact of TCR-Mediated Trogocytosis in $\mathrm{CD}^{+} \mathrm{T}$ Cell Functions}

TCR-pMHC-II interaction results in TCR internalization and a subsequent display of pMHC-II on the surface of $\mathrm{CD} 4^{+} \mathrm{T}$ cells. Several reports have indicated that the trogocytosis of pMHC-II complexes prolongs the association between TCR and PMHC-II complexes, sustains TCR signaling, and promotes the survival of $\mathrm{CD} 4^{+} \mathrm{T}$ cells, even after the removal of APCs [55-57]. Furthermore, a recent report demonstrated that pMHC-II-dressed CD4 ${ }^{+} \mathrm{T}$ cells preferentially differentiate into GATA $3^{+}$Th 2 cells that secrete IL- 4 and IL-5, $72 \mathrm{~h}$ after the removal of APCs [57]. Given that weaker TCR signaling drives polarization toward Th2 cells [58], it can be assumed that weak and sustained TCR signaling triggered by acquired pMHC-II may favor Th2 differentiation. However, another report by Boccasavia et al. demonstrated that pMHC-II-dressed $\mathrm{CD}^{+}{ }^{+} \mathrm{T}$ cells preferentially differentiate into 
regulatory $\mathrm{T}$ cells (Tregs) after presenting acquired antigens to other naïve $\mathrm{T}$ cells [59]. This apparent discrepancy may stem from the difference in the experimental systems they adopted. Further research is required to determine the fate of pMHC-II-dressed CD4 ${ }^{+} \mathrm{T}$ cells under more physiological conditions.

Several reports have indicated that $\mathrm{CD} 4^{+} \mathrm{T}$ cells with acquired pMHC-II complexes can further present antigens to cognate $\mathrm{CD} 4^{+} \mathrm{T}$ cells, leading to $\mathrm{CD} 4^{+} \mathrm{T}$ cell- $\mathrm{T}$ cell interactions [46,59-63]. When MHC-II-dressed $\mathrm{CD}^{+} \mathrm{T}$ cells present antigens to one another, antigen presentation leads to the negative regulation of $\mathrm{CD} 4^{+} \mathrm{T}$ cell responses [32] (Figure 3). Indeed, Tsang et al., revealed that mouse $\mathrm{CD}^{+}{ }^{\mathrm{T}}$ cells that acquire pMHC-II complexes from APCs induce either the apoptosis or anergy of $\mathrm{CD} 4^{+} \mathrm{T}$ cells, possibly through mutual antigen presentation among pMHC-II-dressed $\mathrm{CD} 4^{+} \mathrm{T}$ cells [60]. Helft et al., reported that pMHC-II-dressed $\mathrm{CD} 4^{+} \mathrm{T}$ cells present antigens to memory $\mathrm{CD} 4^{+} \mathrm{T}$ cells, which suppresses the proliferation of memory $\mathrm{CD}^{+} \mathrm{T}$ cells [62]. Thus, antigen presentation by pMHC-IIdressed $\mathrm{CD}^{+} \mathrm{T}$ cells form a negative feedback loop that may limit excess $\mathrm{T}$ cell responses. On the contrary, Boccasavia et al., recently demonstrated that pMHC-II-dressed CD4 ${ }^{+} \mathrm{T}$ cells present antigens to naïve $\mathrm{CD} 4^{+} \mathrm{T}$ cells, which results in differentiation into pathogenic Th17 cells from naïve $\mathrm{CD}^{+} \mathrm{T}$ cells [59] (Figure 3). In a model of experimental autoimmune encephalitis (EAE), mice deficient of RhoG, an essential molecule for TCR-mediated trogocytosis, display ameliorated Th17 inflammation, which results in resistance to EAE development. Therefore, antigen presentation by pMHC-II-dressed $\mathrm{CD} 4^{+} \mathrm{T}$ cells may favor pro-inflammatory Th17 polarization under certain circumstances.

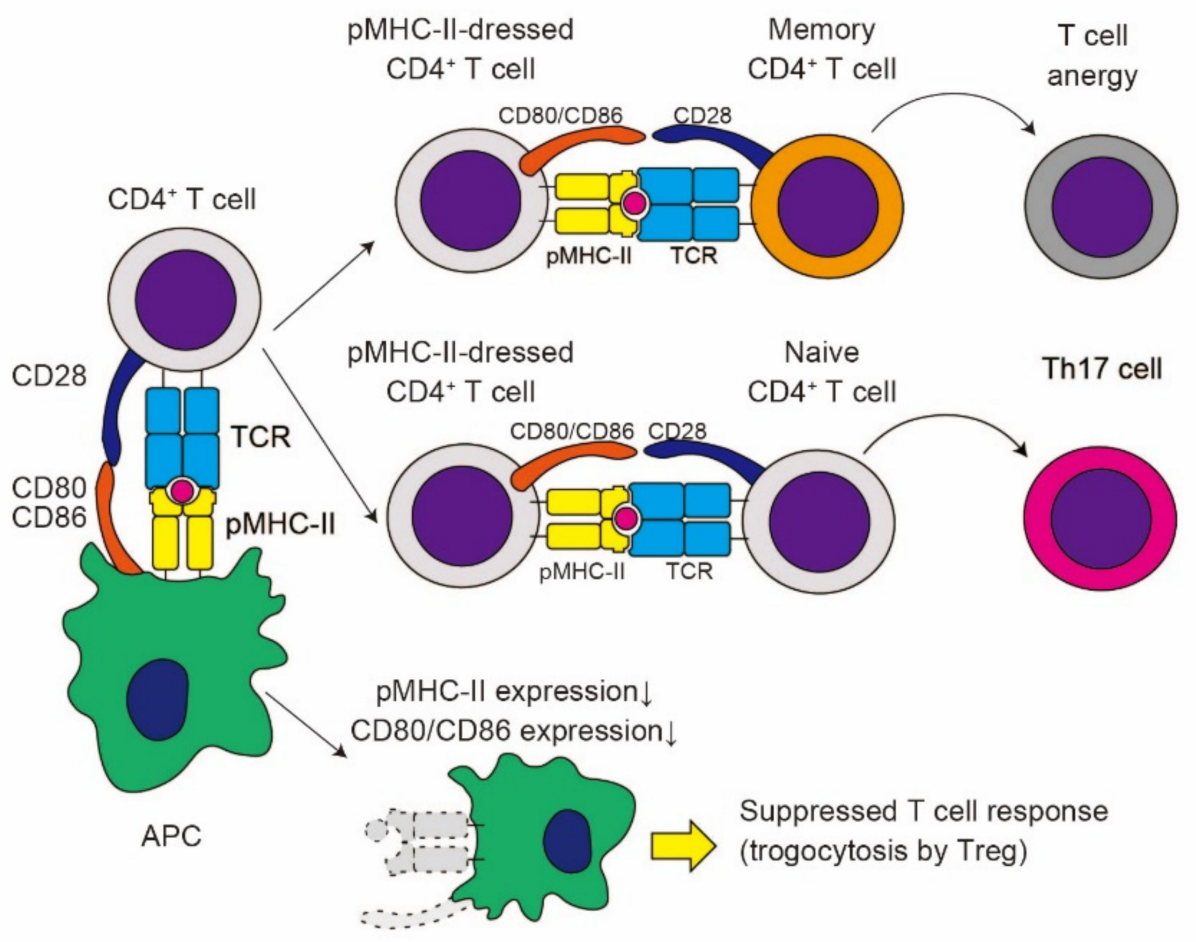

Figure 3. The impact of trogocytosis on $\mathrm{CD}^{+} \mathrm{T}$ cell responses. Upon formation of an immunological synapse, $\mathrm{CD}^{+} \mathrm{T}$ cells acquire pMHC-II complexes from APCs. pMHC-II-dressed CD4 ${ }^{+} \mathrm{T}$ cells can present antigens to memory $\mathrm{CD} 4^{+} \mathrm{T}$ cells, resulting in $\mathrm{T}$ cell anergy, while their antigen presentation to naïve $\mathrm{CD}^{+} \mathrm{T}$ cells may result in differentiation into pathogenic Th17 cells. Moreover, trogocytosis by Tregs can reduce the expression of PMHC-II and co-stimulatory molecules on APCs, leading to the suppression of the $\mathrm{CD}^{+} \mathrm{T}$ cell responses elicited by interaction with APCs.

In addition to the impact on $\mathrm{CD} 4^{+} \mathrm{T}$ cells, TCR-mediated trogocytosis regulates the function of APCs. A recent report by Akkaya et al., revealed that induced regulatory $\mathrm{T}$ cells (iTregs) form intense interactions with DCs, leading to a greater capacity for trogocytosis 
compared to activated $\mathrm{CD} 4^{+} \mathrm{T}$ cells [64]. Thus, iTregs reduce the expression of cognate pMHC-II complexes on the surface of DCs, resulting in the diminished antigen-presenting capacity of DCs (Figure 3). Moreover, iTregs downregulate the expression of CD80 and CD86 on DCs by means of stripping of these co-stimulatory molecules during trogocytosis [65]. Thymus-derived regulatory T cells (tTregs) capture CD80 and CD86 from DCs via trans-endocytosis mediated by cytotoxic T lymphocyte-associated antigen-4 (CTLA-4), leading to impaired co-stimulation by DCs [66,67]. In addition, CTLA-4 on Tregs reportedly extract co-stimulatory molecules from DCs via trogocytosis [68], suggesting the possible role of trogocytosis in CTLA-4-mediated suppression. Additionally, tTregs reduce the expression of CD70 on DCs via trogocytosis mediated by the interaction with CD27 on Tregs, which results in the inhibition of Th1 priming by DCs [69]. Tregs also downregulate CD137 ligand on DCs via CD137-mediated trogocytosis, leading to the suppression of T cell activation by DCs [70]. Collectively, trogocytosis in Tregs suppresses DC functions via multiple pathways.

\subsection{The Impact of TCR-Mediated Trogocytosis on $C D 8^{+} T$ Cell Functions}

$\mathrm{CD}^{+} \mathrm{T}$ cells with pMHC-I complexes acquired from APCs via trogocytosis suppress $\mathrm{T}$ cell responses through multiple pathways. Huang et al. reported that pMHC-I-dressed $\mathrm{CD} 8^{+} \mathrm{T}$ cells are sensitive to the cell lysis by other $\mathrm{CD} 8^{+} \mathrm{T}$ cells, a phenomenon called CD8 ${ }^{+}$ $\mathrm{T}$ cell fratricide [40] (Figure 4). A later report demonstrated that $\mathrm{CD} 8^{+} \mathrm{T}$ cell fratricide can be observed at an extremely high antigen concentration [71], suggesting that the fratricide phenomenon occurs only in the presence of a high antigen concentration. A similar mechanism of fratricide was recently reported in the trogocytosis of $\mathrm{T}$ cells bearing chimeric antigen receptors (CARs) [72], which is further discussed below. CD8 ${ }^{+} \mathrm{T}$ cells also capture CD80 from APCs through trogocytosis [73]. The acquisition of CD80 by memory $\mathrm{CD}^{+} \mathrm{T}$ cells plays a rather suppressive role in their expansion and IL-2 production, suggesting the regulatory role of trogocytosis in recall immune responses.

Trogocytosis by $\mathrm{CD} 8^{+} \mathrm{T}$ cells takes place either when APCs prime $\mathrm{CD} 8^{+} \mathrm{T}$ cells or when $\mathrm{CD} 8^{+} \mathrm{T}$ cells attack target cells, including tumor cells [74,75]. In their interaction with APCs, $\mathrm{CD}^{+} \mathrm{T}$ cells strip pMHC-I complexes from these APCs, which may favor the selective proliferation of $\mathrm{CD} 8^{+} \mathrm{T}$ cells with high-affinity TCR, leading to affinity maturation of CD8 ${ }^{+} \mathrm{T}$ cells [76] (Figure 4). Likewise, $\mathrm{CD} 8^{+} \mathrm{T}$ cells strip pMHC-I complexes from tumor cells [77]. Chung et al. demonstrated that cytotoxic lymphocytes (CTLs) with high-avidity TCR efficiently lyse melanoma cells, while low-avidity CTLs strip pMHC-I complexes from melanoma cells via trogocytosis, leading to the escape from target cell lysis by high-avidity CTLs (Figure 4). Thus, the trogocytosis of pMHC-I complexes from tumor cells blocks CD8 ${ }^{+}$ $T$ cell responses against tumors. Several reports have demonstrated that CD86 and HLA-G expression on T cells indicates the poor prognosis of multiple myeloma [78-80]. Given that CD86 and HLA-G are transferred from tumor cells via trogocytosis [79], trogocytosis of these molecules by $\mathrm{CD} 8^{+} \mathrm{T}$ cells may play a suppressive role in tumor immune responses. 


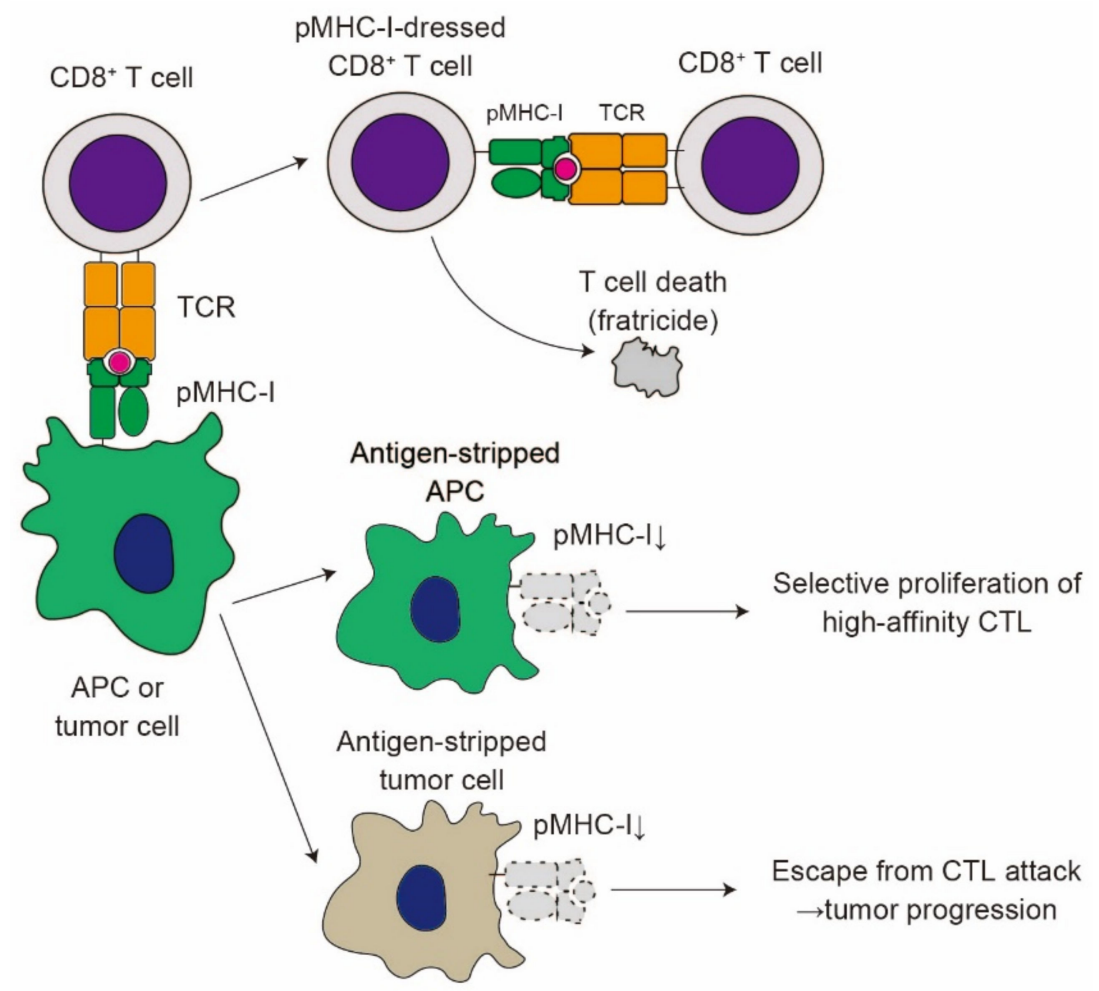

Figure 4. The impact of trogocytosis on $\mathrm{CD}^{+} \mathrm{T}$ cell responses. Upon formation of immunological synapse, $\mathrm{CD}^{+} \mathrm{T}$ cells acquire pMHC-I complexes from APCs or tumor cells. pMHC-I-dressed CD8 ${ }^{+}$ $\mathrm{T}$ cells are susceptible to attack from other $\mathrm{CD} 8^{+} \mathrm{T}$ cells, resulting in cell lysis (fratricide). Trogocytosis reduces the expression of pMHC-I on APCs (antigen stripping). Antigen stripping in APCs favors the selective proliferation of high-affinity CTL. On the contrary, antigen stripping in tumor cells contributes to the escape from CTL attack, leading to tumor progression.

Trogocytosis-mediated antigen stripping has recently been reported in CAR T cells [72]. CAR $T$ cells are engineered $T$ cells that express high-affinity variable fragments of antibody (single-chain variable fragment $(\mathrm{scFv})$ ) fused with an intracellular domain for signal transduction $[81,82]$. Therapies using patient-derived CAR T cells display remarkable efficacy against chemotherapy-resistant or refractory B cell malignancies. However, relapse can be observed in a large proportion of patients, and many patients relapse with antigen-low tumors, leading to escape from CAR T cell therapy $[81,82]$. Hamieh et al., revealed, using a mouse model of leukemia, that the insufficient infusion of CAR T cells causes the trogocytosis of target antigens from tumor cells to CAR T cells [72]. Trogocytosis by CAR T cells reduces the antigen density on target tumor cells, leading to the reduced efficacy of CAR T cell therapy. Moreover, trogocytosis-experienced CAR T cells display an exhausted phenotype and are susceptible to being killed by other $\mathrm{T}$ cells (fratricide). These results indicate that tumor cells exploit trogocytosis for escape from CAR T cell therapy.

\section{Trogocytosis Triggered by Ligand-Receptor Interaction-2: Fc $\gamma$ R-Mediated Trogocytosis}

Immunotherapeutic monoclonal antibodies (mAbs) are utilized to treat a wide variety of disorders, including cancer and autoimmune diseases [83]. After the administration of $\mathrm{mAbs}, \mathrm{Fc} \gamma$ receptor ( $\mathrm{F} c \gamma \mathrm{R})$-expressing cells, including monocytes, macrophages, neutrophils, and NK cells, can extract mAb-bound cell surface molecules from target cells via trogocytosis, leading to the reduced efficacy of mAb-based therapies $[3,84]$ (Figure 5). As observed in TCR-mediated trogocytosis, Fc $\gamma$ R-mediated trogocytosis occurs rapidly (within $1 \mathrm{~h}$ ), accompanies the transfer of membrane patches, and requires actin polymerization [17,85-88]. 


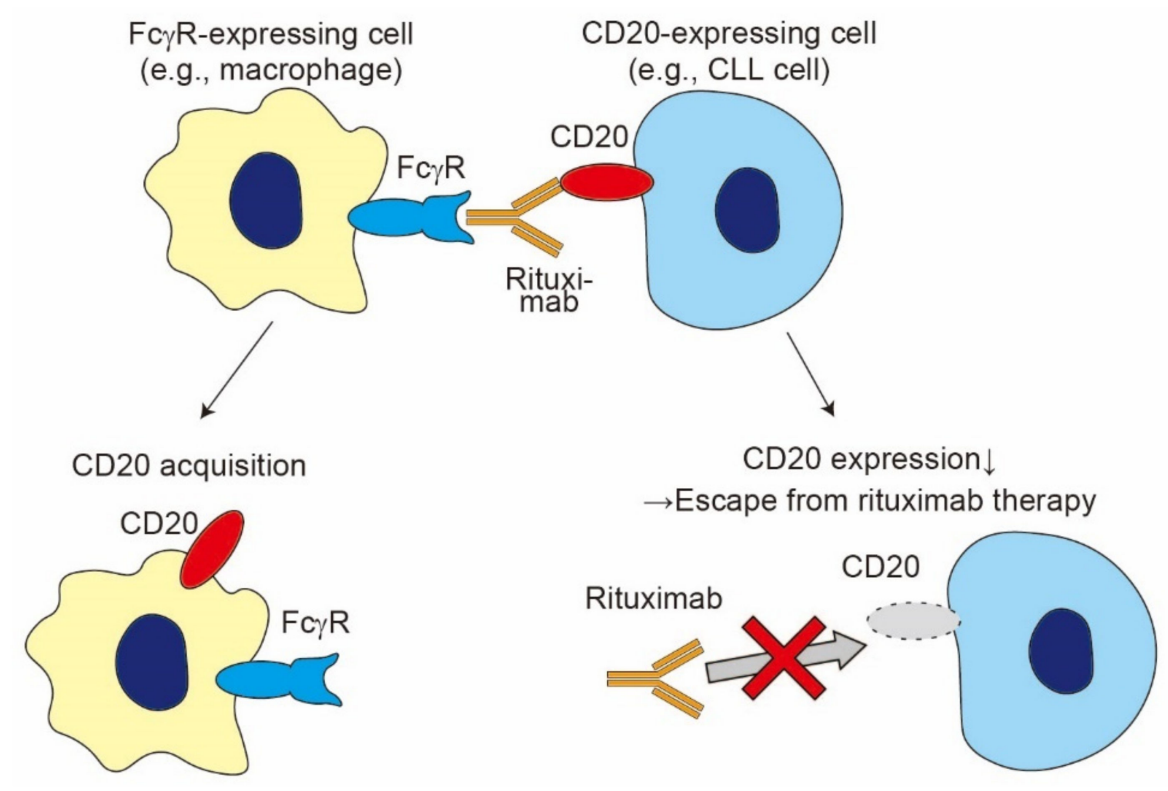

Figure 5. Fc $\gamma$ R-mediated trogocytosis. In rituximab therapy, Fc $\gamma$ R-expressing cells (e.g., macrophages) capture antibody-opsonized cancer cells (e.g., CLL cells), which leads to either the acquisition of CD20 by Fc $\gamma$ R-expressing cells or a reduction in the expression of CD20 in cancer cells and escape from rituximab therapies.

Several reports have suggested that bystander cell surface molecules are also transferred in Fc $\gamma$ R-mediated trogocytosis [89-91]. Rossi et al., revealed that the infusion of epratuzumab (anti-CD22 $\mathrm{mAb}$ ) reduces not only the expression of CD22, but also the expression of other cell surface molecules, including CD19, CD21, and CD79b, on B cells [89], which may favor the efficient inhibition of pathogenic $B$ cell functions in the treatment of systemic lupus erythematosus (SLE).

It remains controversial whether FcgR-mediated trogocytosis requires signaling through Src kinase and PI3K, since conflicting results have been obtained depending on the experimental conditions adopted $[17,85]$. Although several reports have indicated that Fc $\gamma$ R-mediated trogocytosis is rarely observed by incubation on ice $[85,86]$, a recent report suggested that Fc $\gamma$ R-mediated trogocytosis is also operative at $4{ }^{\circ} \mathrm{C}$ [91], suggesting the presence of multiple mechanisms for $\mathrm{F} \gamma \gamma \mathrm{R}$-mediated trogocytosis.

To date, an array of therapeutic mAbs have been reported to cause trogocytosis, including rituximab, epratuzumab, daclizumab, cetuximab, trastuzumab, and daratumumab [86,89,92-96]. Among these mAbs, anti-CD20 mAbs, including rituximab (RTX), ofatumumab (OFA), and obinutuzumab (OBZ), are the best-characterized ones to cause trogocytosis-mediated antigen stripping from tumor cells $[85,86,92,93]$. RTX infusion in patients with chronic lymphocytic leukemia (CLL) rapidly decreases the surface expression of CD20 on tumor cells via trogocytosis, resulting in the incomplete lysis of tumor cells $[85,97]$. Interestingly, regular-dose anti-CD20 mAb therapy promotes the excess consumption of complement system during the first antibody infusion [97]. Such complement depletion, along with a reduction of surface CD20 expression, induces resistance to anti-CD20 mAb therapy $[97,98]$. Taylor et al., proposed that low-dose anti-CD20 mAb therapy can prevent both excess complement consumption and trogocytosis-mediated CD20 reduction, leading to the increased efficacy in tumor cell death [3]. Indeed, Williams et al., demonstrated that low-dose RTX treatment reduces the occurrence of trogocytosis and enhances the clearance of circulating CLL cells [99].

Beum et al., reported that Fc $\gamma$ RI on monocytes is internalized after Fc $\gamma$ R-mediated trogocytosis [92]. Interestingly, a recent report by Pinney et al., revealed that macrophages show a reduced capacity for phagocytosis (termed hypophagia) after rituximab treatment, possibly through the reduction of surface Fc $\gamma$ RI in macrophages [100]. Although it remains 
to be elucidated whether trogocytosis is associated with hypophagia, it can be assumed that the trogocytosis-mediated loss of $\mathrm{F}_{\mathrm{c}} \gamma \mathrm{RI}$ results in the hypophagia of macrophages, which provides another possible mechanism for resistance to RTX therapies.

Taken together, Fc $\gamma \mathrm{R}$-mediated trogocytosis contributes to the resistance to $\mathrm{mAb}$ based therapies, mainly through the loss of target antigens. However, it should be noted that Fc $\gamma$ R-mediated trogocytosis in neutrophils or macrophages can enhance target cell death via trogoptosis [28,36], as described in Section 2. On the contrary, Valgardsdottir et al., revealed that RTX-mediated trogocytosis has little effect on tumor cell death [93]. Further research is required to elucidate which factor(s) causes the different consequences of Fc $\gamma$ R-mediated trogocytosis.

\section{Trogocytosis Triggered by Ligand-Receptor Interaction-3: NK Receptor-Mediated Trogocytosis}

In 2001, three reports demonstrated that the formation of an immunological synapse between NK cells and target cells results in the trogocytosis of pMHC-I complexes and membrane fragments from target cells to NK cells [101-103]. MHC-I acquisition by NK cells is mediated by inhibitory NK cell receptors that recognize MHC-I, including Ly49 receptor (mouse) and killer Ig-like receptor (KIR)2DL1 (human). As observed in TCR-mediated trogocytosis, the trogocytosis of pMHC-I complexes accompanies the transfer of membrane patches, which is dependent on Src kinase-signaling and actin polymerization [104]. Furthermore, a subsequent report revealed that the transfer is bidirectional, in that inhibitory NK cell receptors are also transferred from NK cells to target cells [27].

In mouse studies, it has been revealed that $\mathrm{Ly}_{49 \mathrm{~A}^{+}} \mathrm{NK}$ cells that acquire external MHC$\mathrm{I}\left(\mathrm{H}-2 \mathrm{D}^{\mathrm{d}}\right)$ display reduced cytotoxic functions, possibly due to cis interactions between inhibitory Ly49A and MHC-I on NK cells [102,103]. Similarly, human activated NK cells capture HLA-G from tumor cells, and NK cells that acquire HLA-G cease proliferation and reduce their cytotoxic capacity [105]. Moreover, HLA-G-dressed NK cells suppress the cytotoxic function of other NK cells expressing ILT2, the inhibitory receptor for HLA$\mathrm{G}$, which possibly leads to the immune escape of HLA-G-expressing tumor cells. These observations suggest that inhibitory NK receptor-mediated trogocytosis suppresses NK cell responses.

Moreover, later reports have demonstrated that NK cells acquire ligands for activating NK cell receptors via trogocytosis $[106,107]$. Nakamura et al. revealed that the natural killer group 2 membrane D (NKG2D) on NK cells extracts Rae-1, a ligand for NKG2D, from target cells [106]. Interestingly, Rae-1-dressed NK cells are further lysed by other NK cells expressing NKG2D (NK cell fratricide), which may act as a negative regulator of activated NK cells. Miner et al. reported that another activating NK cell receptor Ly49H also captures a ligand for Ly49H, m157 [107]. The acquisition of m157 on NK cells rather blocks NK cell effector functions mediated by $\mathrm{Ly} 49 \mathrm{H}$, possible through cis interactions between $\mathrm{m} 157$ and Ly49H on NK cells. Taken together, activating NK cell receptor-mediated trogocytosis can play regulatory roles in NK cell functions.

\section{Trogocytosis-Mediated MHC Transfer}

\subsection{Overview of the Trogocytosis-Mediated Transfer of MHC Molecules}

As described in Section 3, T cells extract MHC molecules from APCs via TCR-mediated trogocytosis. In addition, several reports have demonstrated that various cell types other than T cells acquire either pMHC-I or pMHC-II molecules via trogocytosis. Professional APCs such as DCs can capture the pMHC-I complexes generated by and expressed on other APCs via trogocytosis, enabling them to present antigens to $\mathrm{CD}^{+} \mathrm{T}$ cells without synthesizing peptides by themselves (a process called cross-dressing) [108-110]. On the contrary, non-professional APCs, including NK cells, basophils, and lymph node stromal cells, can capture the pMHC-II complexes expressed on APCs via trogocytosis, enabling them to present antigens to $\mathrm{CD}^{+} \mathrm{T}$ cells $[20,22,111]$. However, it remains to be elucidated what triggers the trogocytosis of $\mathrm{MHC}$ molecules. Providing that trogocytosis is generally 
triggered by receptor-ligand interactions, it can be assumed that some receptors for MHC molecules may trigger trogocytosis in these cells. Further research is required to elucidate the molecular mechanisms underlying trogocytosis-mediated MHC transfer. In this section, we summarize the roles of pMHC-I cross-dressing by DCs and pMHC-II acquisition by non-professional APCs.

\subsection{Transfer of $p M H C-I$ Complexes between DCs (Cross-Dressing)}

DCs present antigens to $\mathrm{CD}^{+} \mathrm{T}$ cells via two major pathways [112,113]: One is a direct pathway for endogenous antigens, which are generated typically when DCs are virally infected; the other is a cross-presenting pathway for exogeneous antigens, including those released from dying cells, in which the cytosolic peptides derived from exogeneous antigens are transported to the endoplasmic reticulum (ER) via transporters associated with antigen processing (TAP).

Trogocytosis can confer the third antigen presentation pathway on DCs, which is called the cross-dressing pathway. In this pathway, DCs capture pMHC-I complexes from target cells and present borrowed pMHC-I to CD8 ${ }^{+} \mathrm{T}$ cells. Dolan et al. demonstrated that DCs acquire OVA peptide-loaded MHC-I from dying cells, leading to the activation of OVA peptide-specific CD8 ${ }^{+}$T cells [108]. Wakim and Beaven revealed that cross-dressed DCs play key roles in $\mathrm{CD}^{+} \mathrm{T}$ cell responses in viral infection models [109]. Recent reports have also indicated the importance of cross-dressed DCs in allograft rejection models $[110,114]$. These data collectively suggest that DCs utilize trogocytosis for the induction of efficient $\mathrm{CD}^{+} \mathrm{T}$ cell responses. Cross-dressing and is impact on $\mathrm{T}$ cell responses would have been discussed by other articles in this issue.

\section{3. pMHC-II Transfer from APCs to Immune Cells Other Than T Cells}

Growing evidence suggests that non-professional APCs play important roles in modulating immune responses [115-117]. The trogocytosis of pMHC-II complexes from APCs can confer an antigen-presenting capacity on non-APCs, including NK cells, basophils, and lymph node stromal cells. In these cells, pMHC-II complexes are selectively transferred from DCs, while other cell surface molecules, including co-stimulatory molecules, are rarely transferred, unlike TCR-dependent trogocytosis [20,22,111]. Therefore, the consequence of MHC-II acquisition via trogocytosis in terms of T cell functions depends on the endogenous expression of co-stimulatory molecules on MHC-II-dressed non-APCs. Nakayama et al. reported that NK cells acquire pMHC-II complexes from DCs and present antigens to T cells [111] (Figure 6). Antigen presentation by MHC-II-dressed NK cells rather suppresses the proliferation of $\mathrm{CD}^{+} \mathrm{T}$ cell, possibly because of their little expression of co-stimulatory molecules on NK cell surface. Dubrot et al. reported that afferent lymphatic epithelial cells (LECs) capture pMHC-II complexes from DCs, and antigen presentation by MHC-IIdressed LECs induces T cell apoptosis and suppresses the proliferation of activated CD4 ${ }^{+}$ T cells, since LECs lack the endogenous expression of co-stimulatory molecules [22]. By contrast, Miyake et al. identified that basophils acquire pMHC-II complexes from DCs, and present acquired antigens to naïve $\mathrm{T}$ cells, leading to the proliferation of $\mathrm{CD}^{+} \mathrm{T}$ cells and the differentiation into Th2 cells [20] (Figure 6). Basophils endogenously express co-stimulatory molecule CD86, which enables MHC-II-dressed basophils to enhance CD4 ${ }^{+}$ $\mathrm{T}$ cell proliferation, unlike NK cells and LECs. 
(A) pMHC-II trogocytosis in NK cells

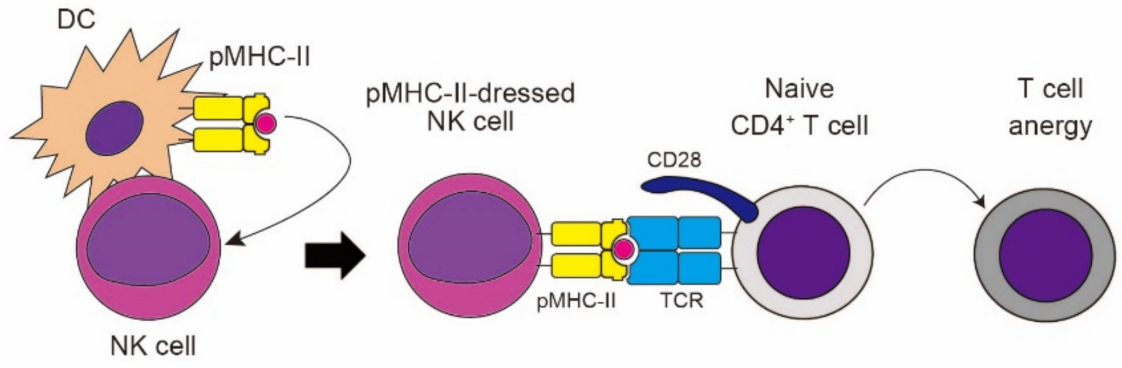

(B) pMHC-II trogocytosis in basophils

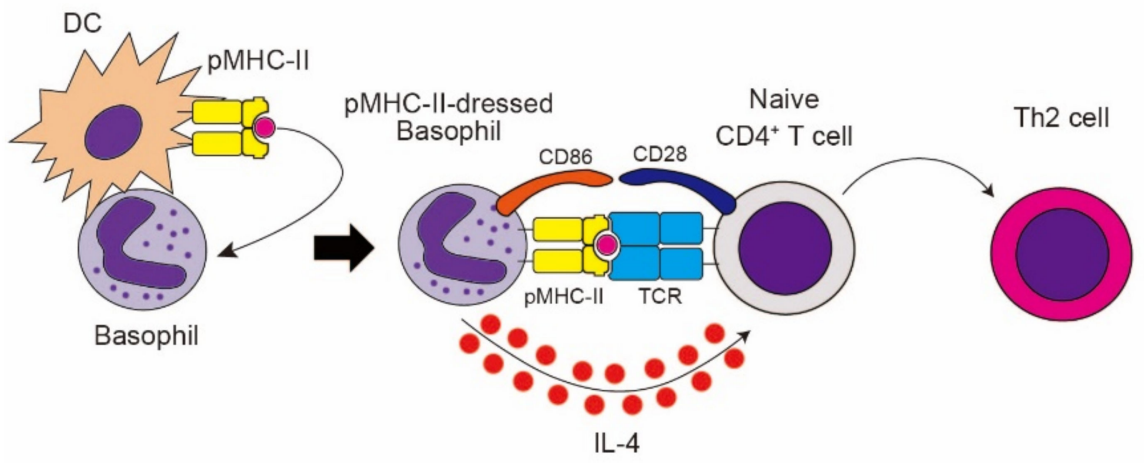

Figure 6. The trogocytosis of pMHC-II in NK cells and basophils. (A) NK cells acquire pMHC-II from APCs via trogocytosis. pMHC-II-dressed NK cells rather suppress CD4 ${ }^{+} \mathrm{T}$ cell responses, possible because of their low expression of co-stimulatory molecules. (B) Basophils acquire pMHC-II from APCs via trogocytosis. pMHC-II-dressed basophils present antigens to naïve $\mathrm{CD} 4^{+} \mathrm{T}$ cells, leading to $\mathrm{T}$ cell proliferation and differentiation into Th2 cells with the aid of the IL-4 produced by basophils.

Basophils are the least common granulocytes, which represent less than $1 \%$ of peripheral blood leukocytes. The functional significance of basophils has long been an enigma, partly because of their rarity and the paucity of analytical tools for basophil research. However, recent research has revealed that basophils play significant roles in various immune responses, including chronic allergic inflammation and protective immunity against parasites [118-121]. Moreover, basophils influence acquired immunity by triggering Th2 differentiation. Of note, mouse and human basophils rapidly secrete large amounts of IL-4 in response to various stimuli [122]. Therefore, it has been assumed that basophils act as accessory cells for Th2 differentiation, in which APCs present antigens to naïve T cells, while basophils provide IL-4 to promote their differentiation into Th2 cells. Supporting this notion, in a papain-induced skin inflammation model, basophils are transiently recruited to draining lymph nodes, and the depletion of basophils impairs Th2 cell differentiation there [123]. Furthermore, subsequent reports have demonstrated that basophils express MHC-II on their cell surface and present antigens to naïve T cells, leading to differentiation into Th2 cells, in concert with IL-4 secreted from basophils [124-126]. They also revealed that depletion of basophils but not DCs impair Th2 differentiation [124,125]. However, later reports have suggested that basophils have little potential for antigen presentation, since they have little expression of antigen-processing machinery, including cathepsin S and invariant chain [127,128]. Moreover, several reports have argued that DCs, rather than basophils, play important roles in Th2 differentiation [127,129]. Trogocytosis-mediated pMHC-II transfer appears to partly reconcile the discrepancy observed in the above-mentioned reports [20]. Basophils can acquire pMHC-II complexes from DCs and can present antigens to T cells, without antigen processing. Trogocytosismediated basophil-DC interplay confers antigen-presenting activity on basophils, which facilitates Th2 differentiation. Therefore, it can be assumed that the extent of basophil-DC interaction may determine the relative contribution of basophils to Th2 differentiation. 
Dudeck et al. demonstrated that mast cells can also acquire MHC-II from DCs and can prime T cell responses [130]. Furthermore, mast cell-DC synapses enhance antigen transfer from mast cells to DCs [131]. Therefore, trogocytosis-mediated mast cell-DC interplay may facilitate cutaneous $\mathrm{T}$ cell responses [132]. Oliphant et al. revealed that group 2 innate lymphoid cells (ILC2s) also express MHC-II on their cell surface, partly via trogocytosis [21]. Interaction between MHC-II-expressing ILC2s and CD4 ${ }^{+} \mathrm{T}$ cells activates T cells to produce IL-2, which, in turn, activates ILC2s to produce IL-5 and IL-13. Taken together, trogocytosis-mediated MHC-II transfer from APCs to other types of cells confers antigen-presenting capacity in non-APCs, leading to the modulation of $\mathrm{CD} 4^{+} \mathrm{T}$ cell immune responses.

\section{Immune Cell Trogocytosis Exploited by Pathogen Microbes}

Recent reports have revealed that the trogocytosis phenomenon is utilized by intracellular bacteria for their spread in hosts [133,134]. Steele et al., demonstrated that macrophages infected with Francisella tularensis bacteria transfer a cytosolic compartment containing viable bacteria to other uninfected macrophages, leading to the spread of intracellular bacteria. Interestingly, F. tularensis infection in macrophages increases the trogocytosis-mediated transfer of cell membrane and cell surface molecules (e.g., MHC), suggesting that intercellular bacterial transfer is associated with trogocytosis [133]. Indeed, uninfected macrophages extract cell fragments, including viable F. tularensis, from infected macrophages in a cell contact-dependent manner $[133,134]$, suggesting the involvement of trogocytosis in bacterial spreading. After the transfer of bacteria, F. tularensis can be detected in double-membraned vesicles, which is composed of a recipient cellderived membrane (outer layer) and a donor cell-derived membrane (inner layer) [134]. F. tularensis bacteria escape from double-membraned vesicles by using a Type 6 secretion system, and they spread to the cytosol of recipient cells [134]. Collectively, trogocytosis in macrophages is exploited by F. tularensis pathogens for their spreading. Of note, it has been demonstrated that several types of intracellular pathogens are transferred directly between immune cells [135-137]. Therefore, it can be postulated that a wide variety of intracellular pathogens utilize trogocytosis by immune cells for their expansion in host cells.

During the infection of avian H5N1 influenza virus, B cells acquire $\alpha 2,3$ sialic acid, the receptor for avian flu, from monocytes via trogocytosis, thus facilitating the spread of influenza virus [138,139]. Interestingly, the trogocytosis-mediated transfer of $\alpha 2,3$ sialic acid is increased by H5N1 influenza infection, suggesting that trogocytosis is also exploited by avian influenza virus. Similarly, NK cells acquire CD21, the receptor for Epstein-Barr virus (EBV), from target cells [140], which may also facilitate EBV spreading. The regulation of trogocytosis could be one measure for preventing the spread of pathogens, including intracellular bacteria and H5N1 influenza virus.

\section{Conclusions}

Immune cells communicate with one another to maintain homeostasis and to eliminate pathogen invasion. Communication among immune cells typically relies on receptorligand interactions, including TCR-MHC interactions. To efficiently exchange information, $\mathrm{T}$ cells and APCs form a specialized structure called an immunological synapse. It is becoming increasingly recognized that the formation of an immunological synapse triggers intercellular protein transfer from APCs to T cells via the process of trogocytosis. Trogocytosis-mediated protein transfer can be observed in other receptor-ligand interactions, including Fc $\gamma$ R- and NK cell receptor-mediated trogocytosis. Trogocytosis can result in both a gain-of-function effect on recipient cells and a loss-of-function effect on donor cells, thus modulating a wide variety of immune reactions. The trogocytosis-mediated transfer of MHC molecules has been observed in various immune and non-immune cells, and confers antigen-presenting activity in non-APCs, leading to the modulation of T cell immune responses. Furthermore, trogocytosis by immune cells is exploited by pathogens. Therefore, the regulation of trogocytosis could be a good target for treating a wide va- 
riety of diseases, including cancer, autoimmune diseases, allergic diseases, and various infectious diseases.

Author Contributions: K.M. wrote the manuscript; H.K. reviewed and edited the manuscript. All authors have read and agreed to the published version of the manuscript.

Funding: This research was funded by the Japan Society for the Promotion of Science (JSPS), grant numbers 20K16277 (to K.M.) and 19H01025 (to H.K.).

Acknowledgments: The authors thank J. Ito and the other members of their laboratory for helpful discussions.

Conflicts of Interest: The authors declare no conflict of interest.

\section{References}

1. Nakayama, M. Antigen presentation by MHC-dressed cells. Front. Immunol. 2014, 5, 672. [PubMed]

2. Campana, S.; de Pasquale, C.; Carrega, P.; Ferlazzo, G.; Bonaccorsi, I. Cross-dressing: An alternative mechanism for antigen presentation. Immunol. Lett. 2015, 168, 349-354.

3. Taylor, R.P.; Lindorfer, M.A. Fcgamma-receptor-mediated trogocytosis impacts mAb-based therapies: Historical precedence and recent developments. Blood 2015, 125, 762-766. [PubMed]

4. Andoh, M.; Ikegaya, Y.; Koyama, R. Synaptic pruning by microglia in epilepsy. J. Clin. Med. 2019, 8, 2170.

5. Dance, A. Core concept: Cells nibble one another via the under-appreciated process of trogocytosis. Proc. Natl. Acad. Sci. USA 2019, 116, 17608-17610. [PubMed]

6. Bettadapur, A.; Miller, H.W.; Ralston, K.S. Biting off what can be chewed: Trogocytosis in health, infection, and disease. Infect. Immun. 2020, 88, e00919-e00930.

7. Li, K.J.; Wu, C.H.; Lu, C.H.; Shen, C.Y.; Kuo, Y.M.; Tsai, C.Y.; Hsieh, S.C.; Yu, C.L. Trogocytosis between non-immune cells for cell clearance, and among immune-related cells for modulating immune responses and autoimmunity. Int. J. Mol. Sci. 2021, $22,2236$.

8. Joly, E.; Hudrisier, D. What is trogocytosis and what is its purpose? Nat. Immunol. 2003, 4, 815.

9. Brown, T. Observations by immunofluorescence microscopy and electron microscopy on the cytopathogenicity of Naegleria fowleri in mouse embryo-cell cultures. J. Med. Microbiol. 1979, 12, 363-371.

10. Ralston, K.S.; Solga, M.D.; Mackey-Lawrence, N.M.; Islamia, J.M.; Bhattacharya, A.; Petri, W.A., Jr. Trogocytosis by Entamoeba histolytica contributes to cell killing and tissue invasion. Nature 2014, 508, 526-530.

11. Islamia, J.M.; Nakada-Tsukui, K.; Nozaki, T. AGC family kinase 1 participates in trogocytosis but not in phagocytosis in Entamoeba histolytica. Nat. Commun. 2017, 8, 101.

12. Saito-Nakano, Y.; Wahyuni, R.; Nakada-Tsukui, K.; Tomii, K.; Nozaki, T. Rab7D small GTPase is involved in phago-, trogocytosis and cytoskeletal reorganization in the enteric protozoan Entamoeba histolytica. Cell. Microbiol. 2021, 23, e13267. [PubMed]

13. Cone, R.E.; Sprent, J.; Marchalonis, J.J. Antigen-binding specificity of isolated cell-surface immunoglobulin from thymus cells activated to histocompatibility antigens. Proc. Natl. Acad. Sci. USA 1972, 69, 2556-2560.

14. Hudson, L.; Sprent, J.; Miller, J.F.; Playfair, J.H. B cell-derived immunoglobulin on activated mouse T lymphocytes. Nature 1974, 251, 60-62.

15. Sharrow, S.O.; Ozato, K.; Sachs, D.H. Phenotypic expression of I-A and I-E/C subregion determinants on murine thymocytes. J. Immunol. 1980, 125, 2263-2268.

16. Sharrow, S.O.; Mathieson, B.J.; Singer, A. Cell surface appearance of unexpected host MHC determinants on thymocytes from radiation bone marrow chimeras. J. Immunol. 1981, 126, 1327-1335.

17. Pham, T.; Mero, P.; Booth, J.W. Dynamics of macrophage trogocytosis of rituximab-coated B cells. PLoS ONE 2011,6, e14498.

18. Bonaccorsi, I.; Morandi, B.; Antsiferova, O.; Costa, G.; Oliveri, D.; Conte, R.; Pezzino, G.; Vermiglio, G.; Anastasi, G.P.; Navarra, G.; et al. Membrane transfer from tumor cells overcomes deficient phagocytic ability of plasmacytoid dendritic cells for the acquisition and presentation of tumor antigens. J. Immunol. 2014, 192, 824-832. [PubMed]

19. Li, K.J.; Wu, C.H.; Shen, C.Y.; Kuo, Y.M.; Yu, C.L.; Hsieh, S.C. Membrane transfer from mononuclear cells to polymorphonuclear neutrophils transduces cell survival and activation signals in the recipient cells via anti-extrinsic apoptotic and MAP kinase signaling pathways. PLoS ONE 2016, 11, e0156262.

20. Miyake, K.; Shiozawa, N.; Nagao, T.; Yoshikawa, S.; Yamanishi, Y.; Karasuyama, H. Trogocytosis of peptide-MHC class II complexes from dendritic cells confers antigen-presenting ability on basophils. Proc. Natl. Acad. Sci. USA 2017, 114, 1111-1116.

21. Oliphant, C.J.; Hwang, Y.Y.; Walker, J.A.; Salimi, M.; Wong, S.H.; Brewer, J.M.; Englezakis, A.; Barlow, J.L.; Hams, E.; Scanlon, S.T.; et al. MHCII-mediated dialog between group 2 innate lymphoid cells and CD4(+) T cells potentiates type 2 immunity and promotes parasitic helminth expulsion. Immunity 2014, 41, 283-295. [PubMed]

22. Dubrot, J.; Duraes, F.V.; Potin, L.; Capotosti, F.; Brighouse, D.; Suter, T.; Gut-Landmann, S.L.; Garbi, N.; Reith, W.; Swartz, M.A.; et al. Lymph node stromal cells acquire peptide-MHCII complexes from dendritic cells and induce antigen-specific CD4(+) T cell tolerance. J. Exp. Med. 2014, 211, 1153-1166. [PubMed] 
23. Rafii, A.; Mirshahi, P.; Poupot, M.; Faussat, A.M.; Simon, A.; Ducros, E.; Mery, E.; Couderc, B.; Lis, R.; Capdet, J.; et al. Oncologic trogocytosis of an original stromal cells induces chemoresistance of ovarian tumours. PLoS ONE 2008, 3, e3894.

24. Weinhard, L.; di Bartolomei, G.; Bolasco, G.; Machado, P.; Schieber, N.L.; Neniskyte, U.; Exiga, M.; Vadisiute, A.; Raggioli, A.; Schertel, A.; et al. Microglia remodel synapses by presynaptic trogocytosis and spine head filopodia induction. Nat. Commun. 2018, 9, 1228.

25. Andoh, M.; Shibata, K.; Okamoto, K.; Onodera, J.; Morishita, K.; Miura, Y.; Ikegaya, Y.; Koyama, R. Exercise reverses behavioral and synaptic abnormalities after maternal inflammation. Cell Rep. 2019, 27, 2817-2825.

26. Lim, T.K.; Ruthazer, E.S. Microglial trogocytosis and the complement system regulate axonal pruning in vivo. eLife 2021, $10, \mathrm{e} 62167$.

27. Vanherberghen, B.; Andersson, K.; Carlin, L.M.; Nolte-'t Hoen, E.N.; Williams, G.S.; Hoglund, P.; Davis, D.M. Human and murine inhibitory natural killer cell receptors transfer from natural killer cells to target cells. Proc. Natl. Acad. Sci. USA 2004, 101, 16873-16878.

28. Matlung, H.L.; Babes, L.; Zhao, X.W.; van Houdt, M.; Treffers, L.W.; van Rees, D.J.; Franke, K.; Schornagel, K.; Verkuijlen, P.; Janssen, H.; et al. Neutrophils kill antibody-opsonized cancer cells by trogoptosis. Cell Rep. 2018, 23, 3946-3959.

29. Davis, D.M. Intercellular transfer of cell-surface proteins is common and can affect many stages of an immune response. Nat. Rev. Immunol. 2007, 7, 238-243.

30. Ahmed, K.A.; Munegowda, M.A.; Xie, Y.; Xiang, J. Intercellular trogocytosis plays an important role in modulation of immune responses. Cell. Mol. Immunol. 2008, 5, 261-269.

31. Rechavi, O.; Goldstein, I.; Kloog, Y. Intercellular exchange of proteins: The immune cell habit of sharing. FEBS Lett. 2009, 583, 1792-1799.

32. Dhainaut, M.; Moser, M. Regulation of immune reactivity by intercellular transfer. Front. Immunol. $2014,5,112$.

33. Gilmartin, A.A.; Ralston, K.S.; Petri, W.A., Jr. Inhibition of amebic lysosomal acidification blocks amebic trogocytosis and cell killing. mBio 2017, 8, e01117-e01187.

34. Gilmartin, A.A.; Ralston, K.S.; Petri, W.A. Inhibition of amebic cysteine proteases blocks amebic trogocytosis but not phagocytosis. J. Infect. Dis. 2020, 221, 1734-1739.

35. Mercer, F.; Ng, S.H.; Brown, T.M.; Boatman, G.; Johnson, P.J. Neutrophils kill the parasite Trichomonas vaginalis using trogocytosis. PLoS Biol. 2018, 16, e2003885.

36. Velmurugan, R.; Challa, D.K.; Ram, S.; Ober, R.J.; Ward, E.S. Macrophage-mediated trogocytosis leads to death of antibodyopsonized tumor cells. Mol. Cancer Ther. 2016, 15, 1879-1889.

37. Bouti, P.; Zhao, X.W.; Verkuijlen, P.; Tool, A.T.J.; van Houdt, M.; Koker, N.; Koker, M.Y.; Keskin, O.; Akbayram, S.; van Bruggen, R.; et al. Kindlin3-dependent CD11b/CD18-integrin activation is required for potentiation of neutrophil cytotoxicity by CD47-SIRP $\alpha$ checkpoint disruption. Cancer Immunol. Res. 2021, 9, 147-155.

38. Olivera-Valle, I.; Latorre, M.C.; Calvo, M.; Gaspar, B.; Gomez-Oro, C.; Collazos, A.; Breton, A.; Caballero-Campo, P.; Ardoy, M.; Asensio, F.; et al. Vaginal neutrophils eliminate sperm by trogocytosis. Hum. Reprod. 2020, 35, 2567-2578.

39. Dustin, M.L.; Choudhuri, K. Signaling and polarized communication across the T cell immunological synapse. Annu. Rev. Cell Dev. Biol. 2016, 32, 303-325.

40. Huang, J.F.; Yang, Y.; Sepulveda, H.; Shi, W.; Hwang, I.; Peterson, P.A.; Jackson, M.R.; Sprent, J.; Cai, Z. TCR-mediated internalization of peptide-MHC complexes acquired by T cells. Science 1999, 286, 952-954.

41. Hudrisier, D.; Riond, J.; Mazarguil, H.; Gairin, J.E.; Joly, E. Cutting edge: CTLs rapidly capture membrane fragments from target cells in a TCR signaling-dependent manner. J. Immunol. 2001, 166, 3645-3649. [PubMed]

42. Wetzel, S.A.; McKeithan, T.W.; Parker, D.C. Peptide-specific intercellular transfer of MHC class II to CD4+ T cells directly from the immunological synapse upon cellular dissociation. J. Immunol. 2005, 174, 80-89. [PubMed]

43. Aucher, A.; Magdeleine, E.; Joly, E.; Hudrisier, D. Capture of plasma membrane fragments from target cells by trogocytosis requires signaling in T cells but not in B cells. Blood 2008, 111, 5621-5628. [PubMed]

44. Martinez-Martin, N.; Fernandez-Arenas, E.; Cemerski, S.; Delgado, P.; Turner, M.; Heuser, J.; Irvine, D.J.; Huang, B.; Bustelo, X.R.; Shaw, A.; et al. T cell receptor internalization from the immunological synapse is mediated by TC21 and RhoG GTPase-dependent phagocytosis. Immunity 2011, 35, 208-222.

45. Hwang, I.; Huang, J.F.; Kishimoto, H.; Brunmark, A.; Peterson, P.A.; Jackson, M.R.; Surh, C.D.; Cai, Z.; Sprent, J. T cells can use either T cell receptor or CD28 receptors to absorb and internalize cell surface molecules derived from antigen-presenting cells. J. Exp. Med. 2000, 191, 1137-1148.

46. Sabzevari, H.; Kantor, J.; Jaigirdar, A.; Tagaya, Y.; Naramura, M.; Hodge, J.; Bernon, J.; Schlom, J. Acquisition of CD80 (B7-1) by T cells. J. Immunol. 2001, 166, 2505-2513.

47. Baba, E.; Takahashi, Y.; Lichtenfeld, J.; Tanaka, R.; Yoshida, A.; Sugamura, K.; Yamamoto, N.; Tanaka, Y. Functional CD4 T cells after intercellular molecular transfer of 0X40 ligand. J. Immunol. 2001, 167, 875-883.

48. Hudrisier, D.; Aucher, A.; Puaux, A.L.; Bordier, C.; Joly, E. Capture of target cell membrane components via trogocytosis is triggered by a selected set of surface molecules on T or B cells. J. Immunol. 2007, 178, 3637-3647.

49. Daubeuf, S.; Aucher, A.; Bordier, C.; Salles, A.; Serre, L.; Gaibelet, G.; Faye, J.C.; Favre, G.; Joly, E.; Hudrisier, D. Preferential transfer of certain plasma membrane proteins onto T and B cells by trogocytosis. PLoS ONE 2010, 5, e8716. 
50. Xiang, J.; Huang, H.; Liu, Y. A new dynamic model of CD8+ T effector cell responses via CD4+ T helper-antigen-presenting cells. J. Immunol. 2005, 174, 7497-7505.

51. He, T.; Zong, S.; Wu, X.; Wei, Y.; Xiang, J. CD4+ T cell acquisition of the bystander pMHC I colocalizing in the same immunological synapse comprising pMHC II and costimulatory CD40, CD54, CD80, OX40L, and 41BBL. Biochem. Biophys. Res. Commun. 2007, $362,822-828$.

52. Ahmed, K.A.; Xie, Y.; Zhang, X.; Xiang, J. Acquired pMHC I complexes greatly enhance CD4(+) Th cell's stimulatory effect on CD8(+) T cell-mediated diabetes in transgenic RIP-mOVA mice. Cell. Mol. Immunol. 2008, 5, 407-415.

53. Romagnoli, P.A.; Premenko-Lanier, M.F.; Loria, G.D.; Altman, J.D. CD8 T cell memory recall is enhanced by novel direct interactions with CD4 T cells enabled by MHC class II transferred from APCs. PLoS ONE 2013, 8, e56999.

54. Delgado, P.; Cubelos, B.; Calleja, E.; Martinez-Martin, N.; Cipres, A.; Merida, I.; Bellas, C.; Bustelo, X.R.; Alarcon, B. Essential function for the GTPase TC21 in homeostatic antigen receptor signaling. Nat. Immunol. 2009, 10, 880-888.

55. Zhou, J.; Tagaya, Y.; Tolouei-Semnani, R.; Schlom, J.; Sabzevari, H. Physiological relevance of antigen presentasome (APS), an acquired MHC/costimulatory complex, in the sustained activation of CD4+ T cells in the absence of APCs. Blood 2005, 105, 3238-3246.

56. Osborne, D.G.; Wetzel, S.A. Trogocytosis results in sustained intracellular signaling in CD4(+) T cells. J. Immunol. 2012, 189, 4728-4739.

57. Reed, J.; Wetzel, S.A. Trogocytosis-mediated intracellular signaling in CD4(+) T cells drives TH2-associated effector cytokine production and differentiation. J. Immunol. 2019, 202, 2873-2887.

58. Yamane, H.; Paul, W.E. Early signaling events that underlie fate decisions of naive CD4(+) T cells toward distinct T-helper cell subsets. Immunol. Rev. 2013, 252, 12-23.

59. Boccasavia, V.L.; Bovolenta, E.R.; Villanueva, A.; Borroto, A.; Oeste, C.L.; van Santen, H.M.; Prieto, C.; Alonso-Lopez, D.; Diaz-Munoz, M.D.; Batista, F.D.; et al. Antigen presentation between T cells drives Th17 polarization under conditions of limiting antigen. Cell Rep. 2021, 34, 108861.

60. Tsang, J.Y.; Chai, J.G.; Lechler, R. Antigen presentation by mouse CD4+ T cells involving acquired MHC class II:peptide complexes: Another mechanism to limit clonal expansion? Blood 2003, 101, 2704-2710.

61. Game, D.S.; Rogers, N.J.; Lechler, R.I. Acquisition of HLA-DR and costimulatory molecules by T cells from allogeneic antigen presenting cells. Am. J. Transplant. 2005, 5, 1614-1625. [PubMed]

62. Helft, J.; Jacquet, A.; Joncker, N.T.; Grandjean, I.; Dorothee, G.; Kissenpfennig, A.; Malissen, B.; Matzinger, P.; Lantz, O. Antigen-specific T-T interactions regulate CD4 T-cell expansion. Blood 2008, 112, 1249-1258. [PubMed]

63. Zhou, G.; Ding, Z.C.; Fu, J.; Levitsky, H.I. Presentation of acquired peptide-MHC class II ligands by CD4+ regulatory T cells or helper cells differentially regulates antigen-specific CD4+ T cell response. J. Immunol. 2011, 186, $2148-2155$.

64. Akkaya, B.; Oya, Y.; Akkaya, M.; Souz, J.A.; Holstein, A.H.; Kamenyeva, O.; Kabat, J.; Matsumura, R.; Dorward, D.W.; Glass, D.D.; et al. Regulatory T cells mediate specific suppression by depleting peptide-MHC class II from dendritic cells. Nat. Immunol. 2019, 20, 218-231.

65. Gu, P.; Gao, J.F.; D'Souza, C.A.; Kowalczyk, A.; Chou, K.Y.; Zhang, L. Trogocytosis of CD80 and CD86 by induced regulatory T cells. Cell. Mol. Immunol. 2012, 9, 136-146. [PubMed]

66. Qureshi, O.S.; Zheng, Y.; Nakamura, K.; Attridge, K.; Manzotti, C.; Schmidt, E.M.; Baker, J.; Jeffery, L.E.; Kaur, S.; Briggs, Z.; et al. Trans-endocytosis of CD80 and CD86: A molecular basis for the cell-extrinsic function of CTLA-4. Science 2011, 332, 600-603. [PubMed]

67. Ovcinnikovs, V.; Ross, E.M.; Petersone, L.; Edner, N.M.; Heuts, F.; Ntavli, E.; Kogimtzis, A.; Kennedy, A.; Wang, C.J.; Bennett, C.L.; et al. CTLA-4-mediated transendocytosis of costimulatory molecules primarily targets migratory dendritic cells. Sci. Immunol. 2019, 4, eaaw0902.

68. Tekguc, M.; Wing, J.B.; Osaki, M.; Long, J.; Sakaguchi, S. CTLA-4-dependent trogocytosis promotes the interactions between Tregs and antigen-presenting cells. J. Immunol. 2020, 204, 228.8.

69. Dhainaut, M.; Coquerelle, C.; Uzureau, S.; Denoeud, J.; Acolty, V.; Oldenhove, G.; Galuppo, A.; Sparwasser, T.; Thielemans, K.; Pays, E.; et al. Thymus-derived regulatory $\mathrm{T}$ cells restrain pro-inflammatory Th1 responses by downregulating CD70 on dendritic cells. EMBO J. 2015, 34, 1336-1348.

70. Luu, K.; Patwardhan, M.V.; Zeng, Q.; Wickstrom, S.L.; Lundqvist, A.; Schwarz, H. Regulatory T cells inhibit T cell activity by downregulating CD137 ligand via CD137 trogocytosis. Cells 2021, 10, 353.

71. Hudrisier, D.; Riond, J.; Garidou, L.; Duthoit, C.; Joly, E. T cell activation correlates with an increased proportion of antigen among the materials acquired from target cells. Eur. J. Immunol. 2005, 35, 2284-2294.

72. Hamieh, M.; Dobrin, A.; Cabriolu, A.; van der Stegen, S.J.C.; Giavridis, T.; Mansilla-Soto, J.; Eyquem, J.; Zhao, Z.; Whitlock, B.M.; Miele, M.M.; et al. CAR T cell trogocytosis and cooperative killing regulate tumour antigen escape. Nature 2019, 568, 112-116.

73. Son, J.M.; Ha, S.J. Extrinsic acquisition of CD80 by antigen-specific CD8(+) T cells regulates their recall immune responses to acute viral infection. Immune Netw. 2019, 19, e25.

74. Riond, J.; Elhmouzi, J.; Hudrisier, D.; Gairin, J.E. Capture of membrane components via trogocytosis occurs in vivo during both dendritic cells and target cells encounter by CD8(+) T cells. Scand. J. Immunol. 2007, 66, 441-450. 
75. Machlenkin, A.; Uzana, R.; Frankenburg, S.; Eisenberg, G.; Eisenbach, L.; Pitcovski, J.; Gorodetsky, R.; Nissan, A.; Peretz, T.; Lotem, M. Capture of tumor cell membranes by trogocytosis facilitates detection and isolation of tumor-specific functional CTLs. Cancer Res. 2008, 68, 2006-2013. [PubMed]

76. Kedl, R.M.; Schaefer, B.C.; Kappler, J.W.; Marrack, P. T cells down-modulate peptide-MHC complexes on APCs in vivo. Nat. Immunol. 2002, 3, 27-32. [PubMed]

77. Chung, B.; Stuge, T.B.; Murad, J.P.; Beilhack, G.; Andersen, E.; Armstrong, B.D.; Weber, J.S.; Lee, P.P. Antigen-specific inhibition of high-avidity T cell target lysis by low-avidity T cells via trogocytosis. Cell Rep. 2014, 8, 871-882. [PubMed]

78. LeMaoult, J.; Caumartin, J.; Daouya, M.; Favier, B.; Le Rond, S.; Gonzalez, A.; Carosella, E.D. Immune regulation by pretenders: Cell-to-cell transfers of HLA-G make effector T cells act as regulatory cells. Blood 2007, 109, 2040-2048.

79. Brown, R.; Kabani, K.; Favaloro, J.; Yang, S.; Ho, P.J.; Gibson, J.; Fromm, P.; Suen, H.; Woodland, N.; Nassif, N.; et al. CD86+ or HLA-G+ can be transferred via trogocytosis from myeloma cells to T cells and are associated with poor prognosis. Blood 2012, 120, 2055-2063.

80. Brown, R.; Suen, H.; Favaloro, J.; Yang, S.; Ho, P.J.; Gibson, J.; Joshua, D. Trogocytosis generates acquired regulatory T cells adding further complexity to the dysfunctional immune response in multiple myeloma. Oncoimmunology 2012, 1, 1658-1660.

81. June, C.H.; O'Connor, R.S.; Kawalekar, O.U.; Ghassemi, S.; Milone, M.C. CAR T cell immunotherapy for human cancer. Science 2018, 359, 1361-1365.

82. Brown, C.E.; Mackall, C.L. CAR T cell therapy: Inroads to response and resistance. Nat. Rev. Immunol. 2019, 19, 73-74.

83. Hafeez, U.; Gan, H.K.; Scott, A.M. Monoclonal antibodies as immunomodulatory therapy against cancer and autoimmune diseases. Curr. Opin. Pharmacol. 2018, 41, 114-121.

84. Xu, H.; Heyman, B. IgG-mediated suppression of antibody responses: Hiding or snatching epitopes? Scand. J. Immunol. 2020, 92, e12921.

85. Beum, P.V.; Kennedy, A.D.; Williams, M.E.; Lindorfer, M.A.; Taylor, R.P. The shaving reaction: Rituximab/CD20 complexes are removed from mantle cell lymphoma and chronic lymphocytic leukemia cells by THP-1 monocytes. J. Immunol. 2006, 176, 2600-2609.

86. Beum, P.V.; Peek, E.M.; Lindorfer, M.A.; Beurskens, F.J.; Engelberts, P.J.; Parren, P.W.; van de Winkel, J.G.; Taylor, R.P. Loss of CD20 and bound CD20 antibody from opsonized B cells occurs more rapidly because of trogocytosis mediated by Fc receptor-expressing effector cells than direct internalization by the B cells. J. Immunol. 2011, 187, 3438-3447.

87. Iwasaki, S.; Masuda, S.; Baba, T.; Tomaru, U.; Katsumata, K.; Kasahara, M.; Ishizu, A. Plasma-dependent, antibody- and Fcgamma receptor-mediated translocation of CD8 molecules from T cells to monocytes. Cytom. Part A 2011, 79, 46-56.

88. Masuda, S.; Iwasaki, S.; Tomaru, U.; Sato, J.; Kawakami, A.; Ichijo, K.; Sogo, S.; Baba, T.; Katsumata, K.; Kasahara, M.; et al. Mechanism of Fcgamma receptor-mediated trogocytosis-based false-positive results in flow cytometry. PLoS ONE 2012, 7, e52918.

89. Rossi, E.A.; Goldenberg, D.M.; Michel, R.; Rossi, D.L.; Wallace, D.J.; Chang, C.H. Trogocytosis of multiple B-cell surface markers by CD22 targeting with epratuzumab. Blood 2013, 122, 3020-3029.

90. Jones, J.D.; Hamilton, B.J.; Rigby, W.F. Rituximab mediates loss of CD19 on B cells in the absence of cell death. Arthritis Rheum. 2012, 64, 3111-3118.

91. Skopelja-Gardner, S.; Jones, J.D.; Hamilton, B.J.; Danilov, A.V.; Rigby, W.F.C. Role for ZAP-70 signaling in the differential effector functions of rituximab and obinutuzumab (GA101) in chronic lymphocytic leukemia B cells. J. Immunol. 2017, 199, 1275-1282. [PubMed]

92. Beum, P.V.; Mack, D.A.; Pawluczkowycz, A.W.; Lindorfer, M.A.; Taylor, R.P. Binding of rituximab, trastuzumab, cetuximab, or mAb T101 to cancer cells promotes trogocytosis mediated by THP-1 cells and monocytes. J. Immunol. 2008, 181, 8120-8132. [PubMed]

93. Valgardsdottir, R.; Cattaneo, I.; Klein, C.; Introna, M.; Figliuzzi, M.; Golay, J. Human neutrophils mediate trogocytosis rather than phagocytosis of CLL B cells opsonized with anti-CD20 antibodies. Blood 2017, 129, 2636-2644. [PubMed]

94. Zhang, Y.; McClellan, M.; Efros, L.; Shi, D.; Bielekova, B.; Tang, M.T.; Vexler, V.; Sheridan, J.P. Daclizumab reduces CD25 levels on T cells through monocyte-mediated trogocytosis. Mult. Scler. J. 2014, 20, 156-164.

95. Suzuki, E.; Kataoka, T.R.; Hirata, M.; Kawaguchi, K.; Nishie, M.; Haga, H.; Toi, M. Trogocytosis-mediated expression of HER2 on immune cells may be associated with a pathological complete response to trastuzumab-based primary systemic therapy in HER2-overexpressing breast cancer patients. BMC Cancer 2015, 15, 39.

96. Krejcik, J.; Frerichs, K.A.; Nijhof, I.S.; van Kessel, B.; van Velzen, J.F.; Bloem, A.C.; Broekmans, M.E.C.; Zweegman, S.; van Meerloo, J.; Musters, R.J.P.; et al. Monocytes and granulocytes reduce CD38 expression levels on myeloma cells in patients treated with daratumumab. Clin. Cancer Res. 2017, 23, 7498-7511.

97. Beurskens, F.J.; Lindorfer, M.A.; Farooqui, M.; Beum, P.V.; Engelberts, P.; Mackus, W.J.; Parren, P.W.; Wiestner, A.; Taylor, R.P. Exhaustion of cytotoxic effector systems may limit monoclonal antibody-based immunotherapy in cancer patients. J. Immunol. 2012, 188, 3532-3541.

98. Baig, N.A.; Taylor, R.P.; Lindorfer, M.A.; Church, A.K.; LaPlant, B.R.; Pettinger, A.M.; Shanafelt, T.D.; Nowakowski, G.S.; Zent, C.S. Induced resistance to ofatumumab-mediated cell clearance mechanisms, including complement-dependent cytotoxicity, in chronic lymphocytic leukemia. J. Immunol. 2014, 192, 1620-1629. 
99. Williams, M.E.; Densmore, J.J.; Pawluczkowycz, A.W.; Beum, P.V.; Kennedy, A.D.; Lindorfer, M.A.; Hamil, S.H.; Eggleton, J.C.; Taylor, R.P. Thrice-weekly low-dose rituximab decreases CD20 loss via shaving and promotes enhanced targeting in chronic lymphocytic leukemia. J. Immunol. 2006, 177, 7435-7443.

100. Pinney, J.J.; Rivera-Escalera, F.; Chu, C.C.; Whitehead, H.E.; VanDerMeid, K.R.; Nelson, A.M.; Barbeau, M.C.; Zent, C.S.; Elliott, M.R. Macrophage hypophagia as a mechanism of innate immune exhaustion in mAb-induced cell clearance. Blood 2020, 136, 2065-2079.

101. Carlin, L.M.; Eleme, K.; McCann, F.E.; Davis, D.M. Intercellular transfer and supramolecular organization of human leukocyte antigen C at inhibitory natural killer cell immune synapses. J. Exp. Med. 2001, 194, 1507-1517. [PubMed]

102. Sjöström, A.; Eriksson, M.; Cerboni, C.; Johansson, M.H.; Sentman, C.L.; Kärre, K.; Höglund, P. Acquisition of external major histocompatibility complex class I molecules by natural killer cells expressing inhibitory Ly49 receptors. J. Exp. Med. 2001, 194, 1519-1530.

103. Zimmer, J.; Ioannidis, V.; Held, W. H-2D ligand expression by Ly49A+ natural killer (NK) cells precludes ligand uptake from environmental cells: Implications for NK cell function. J. Exp. Med. 2001, 194, 1531-1539. [PubMed]

104. Tabiasco, J.; Espinosa, E.; Hudrisier, D.; Joly, E.; Fournié, J.J.; Vercellone, A. Active trans-synaptic capture of membrane fragments by natural killer cells. Eur. J. Immunol. 2002, 32, 1502-1508. [PubMed]

105. Caumartin, J.; Favier, B.; Daouya, M.; Guillard, C.; Moreau, P.; Carosella, E.D.; LeMaoult, J. Trogocytosis-based generation of suppressive NK cells. EMBO J. 2007, 26, 1423-1433. [PubMed]

106. Nakamura, K.; Nakayama, M.; Kawano, M.; Amagai, R.; Ishii, T.; Harigae, H.; Ogasawara, K. Fratricide of natural killer cells dressed with tumor-derived NKG2D ligand. Proc. Natl. Acad. Sci. USA 2013, 110, 9421-9426.

107. Miner, C.A.; Giri, T.K.; Meyer, C.E.; Shabsovich, M.; Tripathy, S.K. Acquisition of activation receptor ligand by trogocytosis renders NK cells hyporesponsive. J. Immunol. 2015, 194, 1945-1953. [PubMed]

108. Dolan, B.P.; Gibbs, K.D., Jr.; Ostrand-Rosenberg, S. Dendritic cells cross-dressed with peptide MHC class I complexes prime CD8+ T cells. J. Immunol. 2006, 177, 6018-6024.

109. Wakim, L.M.; Bevan, M.J. Cross-dressed dendritic cells drive memory CD8+ T-cell activation after viral infection. Nature 2011, $471,629-632$.

110. Hughes, A.D.; Zhao, D.; Dai, H.; Abou-Daya, K.I.; Tieu, R.; Rammal, R.; Williams, A.L.; Landsittel, D.P.; Shlomchik, W.D.; Morelli, A.E.; et al. Cross-dressed dendritic cells sustain effector T cell responses in islet and kidney allografts. J. Clin. Investig. 2020, 130, 287-294.

111. Nakayama, M.; Takeda, K.; Kawano, M.; Takai, T.; Ishii, N.; Ogasawara, K. Natural killer (NK)-dendritic cell interactions generate MHC class II-dressed NK cells that regulate CD4+ T cells. Proc. Natl. Acad. Sci. USA 2011, 108, 18360-18365.

112. Embgenbroich, M.; Burgdorf, S. Current concepts of antigen cross-presentation. Front. Immunol. 2018, 9, 1643.

113. Blander, J.M. Regulation of the cell biology of antigen cross-presentation. Annu. Rev. Immunol. 2018, 36, 717-753.

114. Li, B.; Lu, C.; Oveissi, S.; Song, J.; Xiao, K.; Zanker, D.; Duan, M.; Chen, J.; Xu, H.; Zou, Q.; et al. Host CD8 $\alpha(+)$ and CD103(+) dendritic cells prime transplant antigen-specific CD8(+) T cells via cross-dressing. Immunol. Cell Biol. 2020, 98, 563-576.

115. Kambayashi, T.; Laufer, T.M. Atypical MHC class II-expressing antigen-presenting cells: Can anything replace a dendritic cell? Nat. Rev. Immunol. 2014, 14, 719-730.

116. Lin, A.; Loré, K. Granulocytes: New members of the antigen-presenting cell family. Front. Immunol. 2017, 8, 1781.

117. Schuijs, M.J.; Hammad, H.; Lambrecht, B.N. Professional and 'amateur' antigen-presenting cells in type 2 immunity. Trends Immunol. 2019, 40, 22-34.

118. Voehringer, D. Recent advances in understanding basophil functions in vivo. F1000Research 2017, 6, 1464.

119. Varricchi, G.; Raap, U.; Rivellese, F.; Marone, G.; Gibbs, B.F. Human mast cells and basophils-How are they similar how are they different? Immunol. Rev. 2018, 282, 8-34. [PubMed]

120. Nakashima, C.; Otsuka, A.; Kabashima, K. Recent advancement in the mechanism of basophil activation. J. Dermatol. Sci. 2018, 91, 3-8.

121. Miyake, K.; Shibata, S.; Yoshikawa, S.; Karasuyama, H. Basophils and their effector molecules in allergic disorders. Allergy 2020. [CrossRef]

122. Yamanishi, Y.; Karasuyama, H. Basophil-derived IL-4 plays versatile roles in immunity. Semin. Immunopathol. 2016, 38, 615-622. [PubMed]

123. Sokol, C.L.; Barton, G.M.; Farr, A.G.; Medzhitov, R. A mechanism for the initiation of allergen-induced T helper type 2 responses. Nat. Immunol. 2008, 9, 310-318.

124. Sokol, C.L.; Chu, N.Q.; Yu, S.; Nish, S.A.; Laufer, T.M.; Medzhitov, R. Basophils function as antigen-presenting cells for an allergen-induced T helper type 2 response. Nat. Immunol. 2009, 10, 713-720.

125. Perrigoue, J.G.; Saenz, S.A.; Siracusa, M.C.; Allenspach, E.J.; Taylor, B.C.; Giacomin, P.R.; Nair, M.G.; Du, Y.; Zaph, C.; van Rooijen, N. MHC class II-dependent basophil-CD4+ T cell interactions promote TH2 cytokine-dependent immunity. Nat. Immunol. 2009, 10, 697-705.

126. Yoshimoto, T.; Yasuda, K.; Tanaka, H.; Nakahira, M.; Imai, Y.; Fujimori, Y.; Nakanishi, K. Basophils contribute to TH2-IgE responses in vivo via IL-4 production and presentation of peptide-MHC class II complexes to CD4+ T cells. Nat. Immunol. 2009, 10, 706-712. 
127. Hammad, H.; Plantinga, M.; Deswarte, K.; Pouliot, P.; Willart, M.A.; Kool, M.; Muskens, F.; Lambrecht, B.N. Inflammatory dendritic cells-Not basophils-Are necessary and sufficient for induction of Th2 immunity to inhaled house dust mite allergen. J. Exp. Med. 2010, 207, 2097-2111.

128. Tang, H.; Cao, W.; Kasturi, S.P.; Ravindran, R.; Nakaya, H.I.; Kundu, K.; Murthy, N.; Kepler, T.B.; Malissen, B.; Pulendran, B. The T helper type 2 response to cysteine proteases requires dendritic cell-basophil cooperation via ROS-mediated signaling. Nat. Immunol. 2010, 11, 608-617.

129. Phythian-Adams, A.T.; Cook, P.C.; Lundie, R.J.; Jones, L.H.; Smith, K.A.; Barr, T.A.; Hochweller, K.; Anderton, S.M.; Hammerling, G.J.; Maizels, R.M.; et al. CD11c depletion severely disrupts Th2 induction and development in vivo. J. Exp. Med. 2010, 207, 2089-2096.

130. Dudeck, J.; Medyukhina, A.; Frobel, J.; Svensson, C.M.; Kotrba, J.; Gerlach, M.; Gradtke, A.C.; Schroder, B.; Speier, S.; Figge, M.T.; et al. Mast cells acquire MHCII from dendritic cells during skin inflammation. J. Exp. Med. 2017, 214, 3791-3811.

131. Carroll-Portillo, A.; Cannon, J.L.; Riet, J.T.; Holmes, A.; Kawakami, Y.; Kawakami, T.; Cambi, A.; Lidke, D.S. Mast cells and dendritic cells form synapses that facilitate antigen transfer for T cell activation. J. Cell Biol. 2015, 210, 851-864.

132. Sumpter, T.L.; Balmert, S.C.; Kaplan, D.H. Cutaneous immune responses mediated by dendritic cells and mast cells. JCI Insight 2019, 4, e123947.

133. Steele, S.; Radlinski, L.; Taft-Benz, S.; Brunton, J.; Kawula, T.H. Trogocytosis-associated cell to cell spread of intracellular bacterial pathogens. eLife 2016, 5, e10625.

134. Steele, S.P.; Chamberlain, Z.; Park, J.; Kawula, T.H. Francisella tularensis enters a double membraned compartment following cell-cell transfer. eLife 2019, 8, e45252. [PubMed]

135. Cambier, C.J.; O’Leary, S.M.; O’Sullivan, M.P.; Keane, J.; Ramakrishnan, L. Phenolic glycolipid facilitates mycobacterial escape from microbicidal tissue-resident macrophages. Immunity 2017, 47, 552-565.e4. [PubMed]

136. Perez, O.A.; Yeung, S.T.; Vera-Licona, P.; Romagnoli, P.A.; Samji, T.; Ural, B.B.; Maher, L.; Tanaka, M.; Khanna, K.M. CD169(+) macrophages orchestrate innate immune responses by regulating bacterial localization in the spleen. Sci. Immunol. 2017, 2, eaah5520. [PubMed]

137. Dragotakes, Q.; Fu, M.S.; Casadevall, A. Dragotcytosis: Elucidation of the mechanism for Cryptococcus neoformans macrophage-tomacrophage transfer. J. Immunol. 2019, 202, 2661-2670. [PubMed]

138. Lersritwimanmaen, P.; Na-Ek, P.; Thanunchai, M.; Thewsoongnoen, J.; Sa-Ard-Iam, N.; Wiboon-ut, S.; Mahanonda, R.; Thitithanyanont, A. The presence of monocytes enhances the susceptibility of B cells to highly pathogenic avian influenza (HPAI) H5N1 virus possibly through the increased expression of $\alpha 2,3$ SA receptor. Biochem. Biophys. Res. Commun. 2015, 464, 888-893.

139. Kongsomros, S.; Thanunchai, M.; Manopwisedjaroen, S.; Na-Ek, P.; Wang, S.F.; Taechalertpaisarn, T.; Thitithanyanont, A. Trogocytosis with monocytes associated with increased $\alpha 2,3$ sialic acid expression on B cells during H5N1 influenza virus infection. PLOS ONE 2020, 15, e0239488.

140. Tabiasco, J.; Vercellone, A.; Meggetto, F.; Hudrisier, D.; Brousset, P.; Fournié, J.J. Acquisition of viral receptor by NK cells through immunological synapse. J. Immunol. 2003, 170, 5993-5998. 